always subsists in such numerous meetings of lively and eager youths, of stbmitting to certain restrictions calculated to preserve the tranquillity of their comrades and that of the citizens. It is to this necessity that, in cases of conflict, the disciplinary jurisdiction of the University authorities responds. However, this end is still more strely attained by the sentiment of the honour of the body, and it is gratifying to have to acknowledge that this conscionsness of their moral solidarity, and of the obligations of honour in the case of every one resulting therefrom, remains alive among German students. I do not mean by this to approve of all the special prescriptions of the cocle of honour of students. There are among the number certain remains of the middle ages of which it would be good to get rid, but this is a thing which can only be done by the students themselves.

(To be continued.)

\section{STRIDULATING CRUSTACEANS}

$A^{\mathrm{T}}$ the November meeting of the Entomological Society of A London, the president, Prof. Westwood, directed the attention of the Society to a letter in NATURE (vol, xvii. p. II) from Mr. Saville Kent, on the above subject, a propos of Mr. WoodMason's recent discovery of the existence of stridulating apparatus in scorpions,

Mr. Wond-Mason remarked that structures in Crustacea, some of which certainly, and all of which probably, are for the production of sounds, were first brought to notice by Hilgendorfin V. der Decken's "Reisen in Ost-Africa (Crustacea)"-but had been independently observed by himself in a number of species during his dredging excursion to the Andaman Islands in 1872 . They were paired organs, as in scorpions, the Mygale, and the Phasma to be brought to notice that night--that is to say, organs working perfectly independently of each other were on each side of the body. In some forms (I.) they were seated partly on the body (carapace) and partly on a pair of appendages; of these some (a) had the scraper on the body and the rasp on the appendages-e.g. Matuta, in which the organs are developed in both sexes; and others $(b)$ had the rasp on the body and the scraper on the appendages-eg. Macrophthalmus et affinia, in which the scraper was formed by a sharp-edged lamellar projection on the meropodite of each of the chelipeds, and the rasp was the crenulated infraorbital margin; in these the apparatus could only be developed in the males, the females having short and small and quite inconspicuous chelipeds, which hardly reached so far as to the margins of the orbits. In others (II.) they were seated wholly on the appendages; in the males of the species of Ocypode the rasp was on one and the scraper on another part of the same appendage; in those of Platyonychus bipustulosus the rasps were on one and the scrapers on another pair of appendages; the walking-legs of the second pair were here very long and robust, and their third joint (meropodite) had its upper margin produced upwards at apex into a sharp ciest (the scraper); both Dana and Milne-Edwards had noticed the remarkable length and structure of this pair of legs, but the former alone had mentioned, in his description of the species, the regular transverse plication of the under surface of the propodite of the chelipeds, which constituted without doubt the rasp. The above did not pretend to be a complete account of stridulating apparatus in Crustacea; but separated as he at present was from notes, drawings, and specimens, he could not go into greater detail. The cases of Macrophthalmus and of Platyonychus had not, he believed, been previously recorded. In the forms alluded to by Mr. Kent, no special sound-producing apparatus seemed to be developed. Everybody who had searched for animals on coral-reefs or had dredged in tropical seas was familiar with the "clicking" sounds emitted by the Alphci and their allies. The sounds which here always accompanied so sudden an opening of their claws to their fullest extent that dislocation seemed imminent each time, might be caused either by the impact of the dactylopodite upon the joint to which it is articulated, or by the forcible withdrawal of the huge stopperlike tooth of the dactylopodite from its pit in the immovable arm of the claw; in which latter case the noises might be susceptible, mutatis mutandis, of the same physical explanation as that pro. duced by the withdrawal of a tightly-packed piston from a cylinder closed at one end. These were the explanations that occurred to him while watching a small species that lived in force amidst the branches of the zoophytes called Spongodes, the masses of which crackled all over when brought to the surface. The sounds in this case resembled very closely those made when sparks were taken by the knuckles from the prime-conductor of a small electrical machine. The sounds emitted by the Sphroromil might possibly be produced by the impact of the terga of the posterior somites upon one another at the end of each movement of extension.

Mr. Wood-Mason then announced the discovery of stridulating organs in Phasmida, in a species of Pterinoxylus, and in illustration of his remarks exhibited an impression of Westwood's plate of Serville's species, $P$. difformipes. Here, as in Crustacea and some other Arthropods, an apparatus working perfectly independently of its feliow was developed on each side of the body. The rough prominent basal portion of the costal nervure of the wings formed the rasp, in connection with which was developed a large oval "speculum," "talc-like spot," or "mirror." The rasps were scraped by the sharp and hard front edges of the tegmina, the dome-like form of which seemed admirably adapted, and pro. bably did, to some extent, serve to increase the sound by resonance. In Serville's species, according to Westwood's figure, the stridulating apparatus appeared to be more highly developed, the "mirror" being more distinct, and the tegminal cavities more spacious. The males of the Pterinoxyli were unknown. We had here another case in which functional stridulating organs are present in females. The only other insects known to him in which stridulating organs were seated partly on the wings and partly on the tegmina were the orthopterous $E$ Edipoda, which, according to Scudder (Amer. Nat. ii, II3), stridulate during flight, in connection with which fact it was interesting to observe that the female Pterinoxyli, though incapable of flight, needed to expand their organs of fight in order to bring their similarly situated apparatus into play.

\section{UNIVERSITY AND EDUCATIONAL INTELLIGENCE}

OXFord.-At Queen's College, James Henry Hickens, Epsom College, has been elected to a Natural Science Scholarship.

Cammidge.-The Rede Lecture will be delivered by Prof. Clerk-Maxwell, in the Senate House, on Friclay, May 24, at half past 2 o'clock, on the T'elephone.

Ourse CoLlEgE--Should this institution ever be transformed into the University of Manchester, it will only be after overcoming a good deal of strong opposition. The Liverpool Town Council are to petition in favour of a new corporation with power to incorporate Owens College and other institutions, and that the new University do not bear any merely local or personal appellation. Naturally, also, the Xorkshire College does not look kindly on the proposal, although until Orvens College resolved to take this step the two institutions were on very friendly terms. We trust some arrangement will be come to ultimately that will satisfy all concerned.

WORKING MEN's COLLEGE.-The Science Classes at the Working Men's College, which, during the last three years have, under Mr. Dunman's teaching, have become so popular and useful a feature of that institution, assembled on Saturday last at the Broad Street Restaurant to celebrate . the termination of a very successful course by a dinner. Mr. Thomas Hughes had promised to be present, but in his compulsory absence Mr. Duninan himself occupied the chair. A pleasing feature of the evening was the presentation to $\mathrm{Mr}$. Dumman, by the students in these classes, of a handsome despatch box as a token of their appreciation of the thoroughly efficient manner in which he has dis charged the duties of science teacher.

Strassiung.- The Extraordinary Professorship of Petro graphy, lately occupied by Prof. Rosenbusch, is to be filled by Dr. Cohen, of Heidelberg.

\section{SCIENTIFIC SERIALS}

THE Fournal of the Russian Chemical and Physical Societies of St. Petersburg (vol. x. No. 3) contains the following papers:On the mono and dioxymalonic acids (Part 2), by R. Petrieff.Researches on the transformation of diethylcarbinol into methyl propylcarbinol, and on the synthesis and the properties of diethylacetic and methylpropylacetic acids, by A: Saytzeff.On the synthesis of diphenylenephenylmethane and of diphenylenetolylmethane, by V. Hemilian.-On the falsification of butter by $P$. Koulechoff.-On the elementary law governing the reci procal actions between currents and magnets, by A. Socoloff. 